\title{
Marketing analysis of "Siam" local rice in South Kalimantan during the pandemic of Covid-19
}

\author{
Abdul Sabur ${ }^{1}$, Retna Qomariah $^{1}$, and Lira Mailena ${ }^{1^{*}}$ \\ ${ }^{1}$ Indonesian Agricultural Technology Assessment and Development South Kalimantan, Banjar Baru, Indonesia \\ ${ }^{2}$ Indonesian Center for Agricultural Technology Assessment and Development, Bogor, Indonesia
}

\begin{abstract}
Social restrictions during the pandemic of Covid-19 caused serious disruptions to the food marketing including marketing of Siam local rice in South Kalimantan. The study aims to analyse the marketing performance and efficiency of Siam local rice in South Kalimantan during the pandemic of Covid-19. The research was conducted in March - June 2020. Respondents were farmers, local traders and wholesalers who were selected using snowball sampling technique. Descriptive analysis was carried out based on the framework of Food Supply Chain Network (FSCN). The data was analysed using quantitative analysis related to marketing efficiency, marketing margin and farmer's share. The finding of this study revealed that marketing of Siam local rice during pandemic of Covid-19 was remains efficient with the efficiency rate at 10 marketing channels ranged from $6.48 \%-10.57 \%$. The lowest marketing margin occurred in channel 4 with the largest $\mathrm{B} / \mathrm{C}$ ratio (2.3) and largest farmer's share $(78.7 \%)$ as well since only farmers and wholesaler were actors in this channel. Group of farmers sold grain to wholesalers and wholesalers processed the grain and sold bulk rice to consumers outside the province Therefore, direct marketing channel between group of farmers and wholesaler need to be strengthened in the new normal.
\end{abstract}

\section{Introduction}

The COVID-19 pandemic requires serious handling program to prevent and suppress the spread of the virus. The Indonesian government has established various policies, including large-scale social restrictions (PSBB) which were regulated in Government Regulation Number 21 year of 2020 which was then regulated in the Regulation of the Minister of Health of the Republic Indonesia Number 9 year of 2020 concerning Guidelines for LargeScale Social Restrictions in the Context of Accelerating Handling of Covid-19. The strategy of large-scale social restrictions will only be effective as long as basic food is available especially rice which was consumed by the majority of Indonesian people [1].

Siam is favourite name of the local rice that consumed by majority of consumers in Kalimantan Selatan since they prefer the small shape and long slender, dry form of rice, the taste of sweet and savoury rice, not spoil easily. Siam rice also suitable for people with

\footnotetext{
*Corresponding author : ellen_bogor@yahoo.com
} 
Diabetes Mellitus since its carbohydrate content was only 48.88 percent [2]. Further, many farmers in South Kalimantan also persist in cultivating this local variety of rice because it had good resistance to agro-ecosystem conditions in this province and has a high production as well. However, social restrictions during the pandemic of Covid-19 caused serious disruptions to the food marketing. Social restriction has increased the distribution cost which in turn increases the transaction cost. Further, Mmbado et al [3] mentioned that high transaction costs have caused decreasing on the farmer price. Meanwhile, the efficient marketing system potentially decreased the transaction cost and hence influenced largely the profitability increase as well [4].

Agricultural marketing system is the process to provide products in the right form, quality, place and time as required by the consumer [5]. The marketing system of Siam local rice in South Kalimantan in the pre-Covid 19 pandemic involved farmers, collectors in the village, traders outside the village, wholesalers and retailers where most of farmers sold grain to collectors since farmers got farm capital loans from collectors and farmers were bound to sell the grain to them, at the same time repay their loan. However, the marketing of Siam local rice during the Covid-19 pandemic has not been studied in depth, so it is not known whether the marketing performance of Siam local rice is efficient and whether the share of farmers remains high and can be an incentive for farmers to produce Siam local rice continuously. Therefore, the study aims to analyse the marketing of Siam local rice in South Kalimantan during the pandemic of Covid-19.

\section{Research methods}

The research was conducted in March - June 2020 and used a survey method. The sampling of farmers was selected randomly and sampling of traders was taken by the snowball technique. The data consisted of secondary and primary data and were analysed descriptively and mathematically.

Marketing analysis of Siam local rice includes marketing efficiency index, marketing margin, marketing benefit to cost ratio and farmer share. Several studies on the marketing efficiency have grouped into two types namely operational and price efficiency $[6,7,8]$. Operational efficiency is related to marketing activities that can increase or maximise the ratio of marketing output to input. Meanwhile, price efficiency is the ability of marketing system to allocate resources and coordinate all agricultural production and marketing processes effectively to meet consumer demand and satisfaction [7].

Operational efficiency analysis of agricultural markets used various indicators and ratios such as marketing cost, marketing margins, farmers share, price spread, benefit to cost ratio and marketing efficiency index $[3,9,10,11]$. Meanwhile, marketing efficiency in this study focused on the operational efficiency with indicators on marketing efficiency index, marketing margins and benefit cost ratio, as well as farmer share. Agricultural marketing was efficient when it had a low marketing efficiency index, low marketing margin, high $\mathrm{B} / \mathrm{C}$ ratio and high farmer share $[6,7]$.

Marketing efficiency index is the ratio between marketing costs and the total value of the product [12]. Marketing efficiency in each marketing agency is formulated as follows:

$$
M E i=\frac{M C i}{T V P i} \times 100 \%
$$

where MEi is marketing efficiency index, MCi is marketing cost (IDR/kg) and TVPi is total value of product (IDR $/ \mathrm{kg}$ ) as represented by the selling price of products. 
Marketing efficiency index was categorized into three criteria as follows:

$0-33 \%=$ efficient

$34-67 \%=$ less efficient

$68-100 \%=$ not efficient

The marketing margin is the difference between the selling price and the buying price which indicates the sum of marketing costs and marketing profits. The marketing margin of each marketing agency according to [13] as follows:

$$
M M i=M C i+M P i
$$

where $\mathrm{MMi}$ is marketing margin of each marketing agency, $\mathrm{MCi}$ is marketing cost (IDR $/ \mathrm{kg}$ ) and MPi is marketing profit (IDR/kg).

Marketing profit to cost ratio was formulated as follows:

$$
P C i=\frac{M P i}{M C i}
$$

where PCi is profit to cost ratio, MPi is marketing profit (IDR/kg) and MCi is marketing cost (IDR/kg).

Farmer shares in each channel as follows:

$$
F S i=\frac{F F i}{C P i}
$$

where FSi is the farmer share, FPi is farmer price (IDR/kg), and CPi is consumer price (IDR $/ \mathrm{kg}$ ). Farmer share is efficient when $\mathrm{FSi} \geq 40 \%$ and $\mathrm{FSi}<40 \%$ is not efficient.

\section{Results and Discussion}

\subsection{Rice marketing channel}

The marketing of Siam local rice was aimed at fulfill the food needs of Banjar etnis in South Kalimantan, Central Kalimantan and East Kalimantan who prefer to consume the dry rice with the small shape and long slender, not spoil easily and good tastes. Consumers in these two provinces have always received a supply of Siam local rice from South Kalimantan because many Banjar peoples lived in these provinces.

Following the framework of the Food Supply Chain Networking (FSCN) by Van der Vorst [14], marketing of Siam local rice through three main channels as shown by red, yellow and green line in Figure 1. Further, those three main channels expanded practically into 10 channels due to variation of product (Figure 1).

Marketing agent on main channel I (red line) consist of farmer/group of farmers, wholesalers, retailers and consumers. Farmers or groups of farmer sold harvested dry grain (GKP) or milled dry rice (GKG) directly to wholesalers through their collaborators in the field and farmers got direct payment in the same day. Wholesalers grind the rice in the small and medium rice milling unit in the village and transported it to their warehouses before being distributed to retailers within and outside the province with a delayed payment 
about 2-3 weeks which and then sold it to end consumers. Main channel I was expanded into channel 1, 2 and 3.

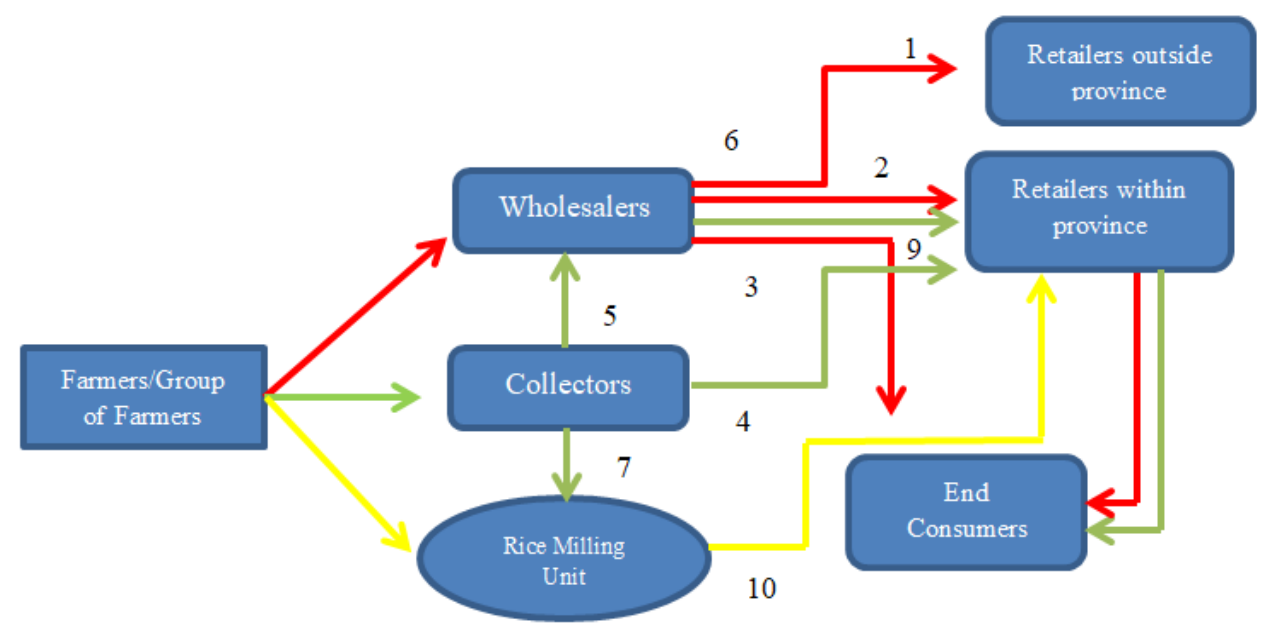

Fig.1. Marketing Channel of Siam Local Rice during Pandemic Covid 19 in South Kalimantan

The main channel II, which is shown by the green line, consists of five marketing agents, namely farmers, collectors, wholesalers, rice millers, retailers and consumers. Farmers sold their milled dry rice (GKG) to collector and collector then sold it directly to wholesalers and to rice millers. Besides selling the milled dry rice (GKG), collectors also grind it to the small and medium Rice Milling Unit (RMU) in the village and sold the rice to wholesalers or retailers to be marketed to end consumers. Collector in this channel can act as an accomplice to wholesaler or RMU who usually provide farming capital for farmers. The main channel II was divided into channel 4,5,6,7,8 dan 9. This channel occurs in almost all rice production centers such as the rice marketing channel in Wawotobi District, Konawe Regency, Southeast Sulawesi Province [15].

Further, main channel III is shown by a yellow line with four marketing agents, namely farmers, rice millers, retailers and consumers. Retailers in this channel were not always small traders who sold unpackaged rice products, but also sold the packed rice to department stores or wholesalers. However, the main obstacle faced by rice millers in utilizing modern retail channels was the delayed payment system which reduces business capital and the complexity of licensing and sales documents that should be fulfilled to sell product to the modern retail. Main channel III was indicated by channel 10 .

Before the Covid 19 pandemic, main channel II was dominant where the portion of grain sales to collector was very large (75\%) since farmers got farming loans from collectors and farmers were bound to sell the grain to collector at once to pay off their loans. However, the purchase price from collectors was lower than price to wholesalers and millers. Meanwhile, during the Covid 19 pandemic, the portion of sales to the main channel I, namely direct sales to wholesalers, increased due to distribution restrictions made the rice supply from collectors to wholesalers greatly reduced and encouraged wholesalers to buy the grain directly from farmers. The difference in the portion of local rice sales through three main channels is presented in Table 1. 
Table 1. The portion of sales of local rice through three marketing channels

\begin{tabular}{|c|c|c|}
\hline Marketing Channel & \multicolumn{2}{|c|}{ The Sale Portion (\%) } \\
\cline { 2 - 3 } & $\begin{array}{c}\text { Before Covid 19 } \\
\text { Pandemic }\end{array}$ & $\begin{array}{c}\text { During Covid 19 } \\
\text { Pandemic }\end{array}$ \\
\hline $\begin{array}{c}\text { Channel I: farmers/group of farmers, wholesalers, } \\
\text { retailers and consumers }\end{array}$ & $75 \%$ & $50 \%$ \\
\hline $\begin{array}{c}\text { Channel II: farmers/group of farmers, collectors, } \\
\text { wholesalers, rice millers, retailers and consumers }\end{array}$ & $20 \%$ & $40 \%$ \\
\hline $\begin{array}{c}\text { Channel III: farmers/group of farmers, rice millers, } \\
\text { retailers and consumers }\end{array}$ & $5 \%$ & $10 \%$ \\
\hline
\end{tabular}

\subsection{Marketing efficiency index}

The result of marketing efficiency index of each channel as presented in Table 2 range from 6.48 to 11.38 and indicated that marketing of Siam local rice during Pandemic Covid 19 was still efficient. Table 2 shows that out of 10 channels, marketing on channel 2 was the most efficient with efficient index of 6.48 percent since wholesalers directly process farmers' grain into rice and sold it to final consumers. In this channel there were not many marketing agents were involved and not many marketing activities were carried out so that it produced the smallest marketing efficiency index. The small value of marketing efficiency index also indicated the efficient function of marketing agents [16]. Otherwise, channel 10 has the highest index of marketing efficiency $(11.38 \%)$ but still efficient with marketing agents namely farmers, rice millers, retailers and consumers. It was presumably due to the high costs incurred during processing and special treatment such as sorting and packaging, which of course also had an impact on the length of time it takes to work and high cost of labour.

Table 2. Marketing efficiency index of each channel of Siam local rice during Covid 19 pandemic

\begin{tabular}{|c|c|c|c|c|c|c|c|c|c|c|}
\hline \multirow[t]{2}{*}{ Item } & \multicolumn{10}{|c|}{ Channel } \\
\hline & 1 & 2 & 3 & 4 & 5 & 6 & 7 & 8 & 9 & 10 \\
\hline $\begin{array}{c}\text { Total Value of Product } \\
(000 \mathrm{IDR} / \mathrm{kg})\end{array}$ & 113 & 108 & 123 & 113 & 113 & 113 & 123 & 123 & 123 & 123 \\
\hline $\begin{array}{c}\text { Marketing Cost (000 } \\
\text { IDR/kg) }\end{array}$ & 10 & 7 & 13 & 9 & 10 & 10 & 13 & 13 & 13 & 14 \\
\hline Marketing Efficiency (\%) & 8.85 & 6.48 & 10.57 & 7.96 & 8.85 & 8.85 & 10.57 & 10.57 & 10.57 & 11.38 \\
\hline
\end{tabular}

Source : Primary data, 2020

\subsection{Marketing margin of Siam local rice}

Based on Food Supply Chain Networking (FSCN) by Van der Vorst (2006), it is known that the amount of marketing costs during the Covid 19 pandemic in the South Kalimantan region differed between channels due to the type of product (GKP or GKG and rice), location, agencies, and marketing activities. This is in line with the opinion of [4] that the amount of marketing costs differ from one channel to another due to the type of commodity, marketing location, types of marketing institutions and marketing activities. Components of marketing costs include cost of transportation, storage, milling process, and drying. The results of the marketing margin for each channel are presented in Table 3 
where the details of the cost, price, and profit of each marketing agent were calculated for "one blek" as a local unit in South Kalimantan which was equivalent to $10 \mathrm{~kg}$.

Table 3. Marketing margin and profit to cost ratio of Siam local rice during Covid 19 pandemic

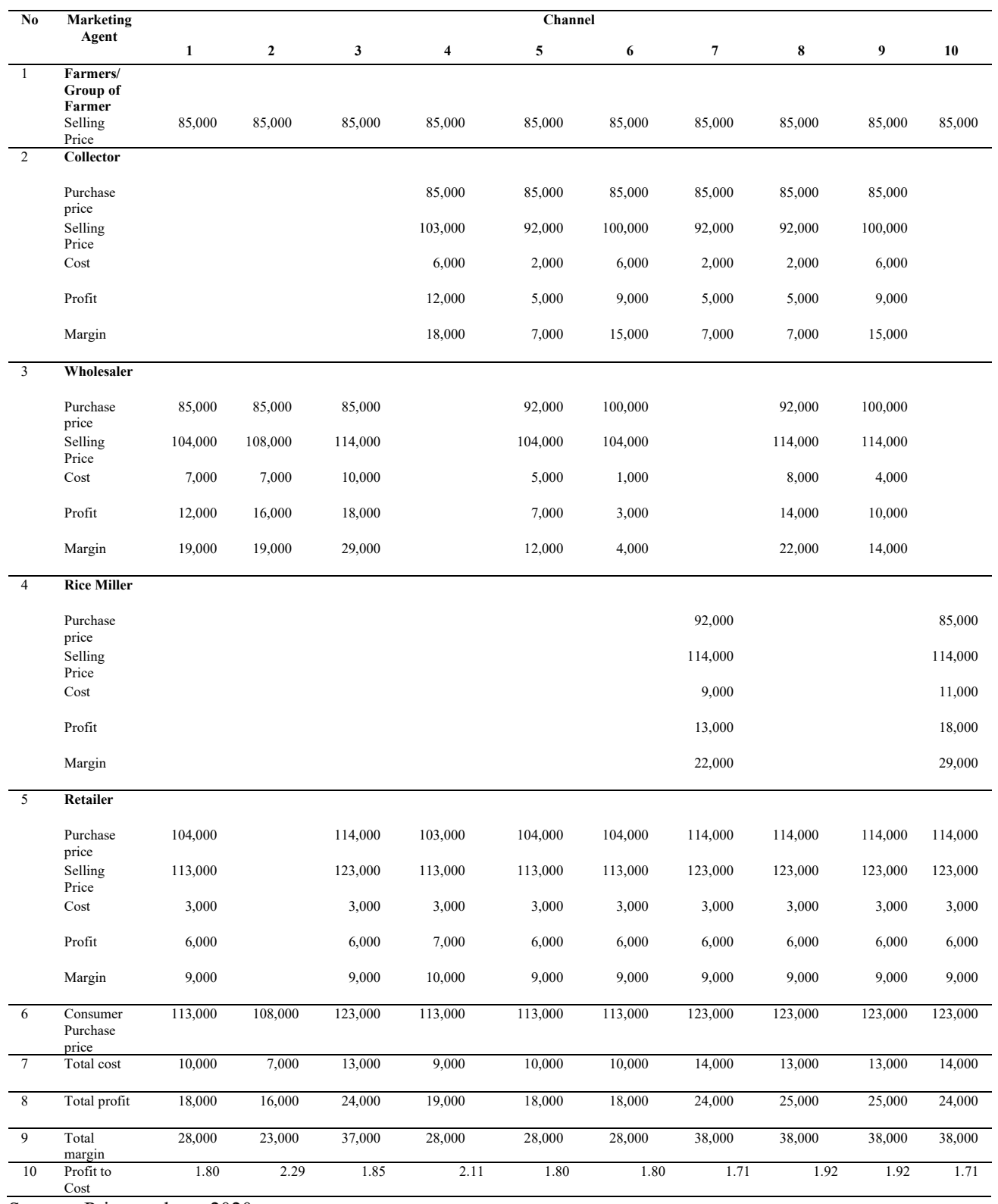

Source : Primary data, 2020 
Channel 2 has the lowest total marketing margin where marketing agents involved in this channel only farmer, wholesalers and consumers. In this channel, there was no intermediary merchant function and all the functions of collecting traders and retailers were carried out by wholesalers. Wholesalers bought farmers' harvested dry grain and directly process it into rice and distribute it to consumers, thereby reducing marketing costs since only paid the transportation costs and the cost of processing harvested dry grain into rice. As an illustration, the total cost incurred is IDR 7,000/blek, and a total profit of IDR $16,000 /$ blek, thus providing a marketing margin of only IDR 23,000 / bottle. This result was in line with the result of marketing efficiency index where channel 2 also had the smallest index.

The highest total margins were on channels $7,8,9$ and 10 , amounting to IDR $38,000 /$ blek. In each of these channels, there were 5 marketing agents involved so that the functions performed were more diverse, which results in higher costs and higher profits. This can be seen in channels 7 and 10, although GKP was taken from both farmers and collectors at the same price as the wholesaler purchase price, but the next process was different. If the wholesaler was paid only the transport and processing costs, the rice miller continued the process of sorting and packaging, which also required more costs and labour. Likewise, it happened also to channels 8 and 9 whereas although the function of each component was same as function on channel 2 and 5, the marketing margins on these two channels were higher than others due to the additional freight costs between provinces. It showed that the longer the rice marketing channels with many involved agents, the higher the marketing margin. As consequence, the higher the price paid by consumer as well [4].

The amount of profit and costs for each marketing channel of Siam local rice were analysed by the profit to cost ratio. Based on data in Table 2, the values of profit to cost ratio for each channel were more than 1 and indicated that the business processes on each channel were profitable. This result also showed that the profit from each channel was higher than the costs and all channels were worth working on. The highest value of profit to cost ratio was 2.3 on channel 2 and the lowest ratio on channel 7 and 10 with a value of 1.7 respectively.

\subsection{Farmer share}

Farmer share is calculated based on the comparison of the purchase price from the farmer with the price at the consumer level. The greater the value of farmer share, the marketing of rice. The farmer's price for all channels is IDR 85,000, which means that the farmer sells grain at that price level. Determination of the price of grain is usually based on the highest price that was informed by collectors and wholesalers who compete to get farmers' grain as well as from fellow farmers.

Table 4 shows that the highest farmer share was in channel 2 because there were only two agents involved in this channel, namely farmers and wholesalers. The few agents involved in marketing channel make the profit share more optimal and consumers get a nominally cheaper price at Rp. 108,000/blek. Meanwhile, on channel 3,7,8,9,10 the consumer purchase price become higher at Rp. 123,000/blek and farmers did not get a bigger share since the profits were shared among many marketing agents, namely collectors, wholesalers, rice millers and retailers. This result revealed clearly that short marketing chain of Siam local rice provides the great benefits for farmers and consumers as well. 
Table 4. Farmer shares in Siam local rice marketing during the pandemic of Covid 19

\begin{tabular}{cccccccc}
\hline Channel & $\begin{array}{c}\text { Farmer } \\
\text { price }\end{array}$ & $\begin{array}{c}\text { Collector } \\
\text { price }\end{array}$ & $\begin{array}{c}\text { Wholesaler } \\
\text { price }\end{array}$ & $\begin{array}{c}\text { Rice } \\
\text { miller } \\
\text { price }\end{array}$ & $\begin{array}{c}\text { Retailer } \\
\text { price }\end{array}$ & $\begin{array}{c}\text { Consumer } \\
\text { price }\end{array}$ & $\begin{array}{c}\text { Farmer } \\
\text { share }\end{array}$ \\
\hline 1 & 85,000 & & 104,000 & & 113,000 & 113,000 & $75.22 \%$ \\
2 & 85,000 & & 108,000 & & & 108,000 & $78.70 \%$ \\
3 & 85,000 & & 114,000 & & 123,000 & 123,000 & $69.11 \%$ \\
4 & 85,000 & 103,000 & & & 113,000 & 113,000 & $75.22 \%$ \\
5 & 85,000 & 92,000 & 104,000 & & 113,000 & 113,000 & $75.22 \%$ \\
6 & 85,000 & 100,000 & 104,000 & & 113,000 & 113,000 & $75.22 \%$ \\
7 & 85,000 & 92,000 & & 114,000 & 123,000 & 123,000 & $69.11 \%$ \\
8 & 85,000 & 100,000 & 114,000 & & 123,000 & 123,000 & $69.11 \%$ \\
9 & 85,000 & 100,000 & 114,000 & & 123,000 & 123,000 & $69.11 \%$ \\
10 & 85,000 & & & 114,000 & 123,000 & 123,000 & $69.11 \%$ \\
\hline
\end{tabular}

Source; Primary data

\section{Conclusions}

The finding of this study revealed that marketing of Siam local rice during pandemic of Covid-19 was remains efficient with the efficiency rate at 10 marketing channels ranged from $6.48 \%-10.57 \%$. The lowest marketing margin occurred in channel 2 with the largest $\mathrm{B} / \mathrm{C}$ ratio (2.3) and largest farmer's share $(78.7 \%)$ only farmers and wholesaler were actors in this channel. Group of farmers sold grain to wholesalers and wholesalers processed the grain and sold bulk rice to consumers outside the province. Therefore, development of Siam local rice agribusiness development in the new normal should be pursued by strengthening the direct marketing system between group of farmers and wholesaler which is equipped with a marketing contract that binds both parties.

Author Contribution. Team authors contributed equally to this works.

\section{References}

1 K.B. Andri. Strategi pertanian menghadapi pandemi Covid 19 [Internet]. [diunduh 2020 Agu 17]. https://mediaindonesia. com/read/detail/308928-strategi-pertanianmenghadapi-pandemi-covid19 (2020)

2 F. Mahyudi. Media Sains, 9, 2 (2016)

3 F.E. Mmbando, E.Z. Wale, L.J.S. Baiyegunhi. Agrekon 54 (2015)

4 Y.J. Mgale, Y. Yunxian. Australian Journal of Agricultural and Resource Economics, $59(2020)$

5 M. Schermer. Agric Hum Values, 32 (2015)

6 R.L. Kohls, J.N. Uhl, Marketing of Agricultural Products, 9th edn. (Macmillan Publishing Company, New York. 2002)

7 M. Fafchamps, E. Gabre-Madhin, B. Minten. Journal of Development Economics, 78 (2005) 
8 B. Irawan. Analisis Kebijakan Pertanian, 5, 4 (2007)

9 R.K. Panda, R. Sreekumar. Journal of International Food \& Agribusiness Marketing, 24 (2012).

10 G.C. Romero, M. Wollni. Agricultural Economics, 49 (2018)

11 S.M. Asil, A. Yuichiro, I. Hiroshi, H. Najibullah, S. Ito. Journal of the Faculty of Agriculture, Kyushu University, 63 (2018)

12 E. Suminartika, I. Djuanalia. Mimbar Agribisnis, 3, 1 (2017)

13 N. Widiastuti, M. Harisudin. Jurnal SEPA, 9, 2 (2013)

14. V.D. Vorst. Performance Measurement in Agri-Food Supply Chain Networks. (Netherland Logistics and Operations Research Group, Wageningen University 2006)

15 L. Saleh. Jurnal Agro Sains, 4 (2020)

16 R.K. Panda, Sreekumar. Journal of International Food \& Agribusiness Marketing, 24 (2012) 